\title{
Gedetineerd en debiteur
}

\section{Onderzoek naar het hebben van schulden tijdens en na detentie*}

\author{
Rosa Koenraadt, Anja Dirkzwager \& Paul Nieuwbeerta
}

\section{Introductie}

Terwijl in Nederland al ongeveer één op de vijf huishoudens schulden heeft, ${ }^{1}$ betreft de gevangenispopulatie een groep waar een nog hogere prevalentie van schuldenproblematiek te vinden is. Geschat wordt dat in Nederland meer dan de helft van de gedetineerden schulden heeft en ook na detentie lijkt meer dan de helft schulden af te moeten lossen. ${ }^{2,3}$ Het hebben van schulden kan verschillende problemen tot gevolg hebben. Zo toont onderzoek aan dat het hebben van schulden zijn weerslag heeft op de executieve functies en het psychisch en fysiek welbevinden van een schuldenaar. ${ }^{4,5,6}$ Tevens hebben verschillende studies een verband aangetoond tussen het hebben van schulden en het plegen van criminaliteit, waarbij er gesuggereerd wordt dat het hebben van schulden een belangrijke rol kan spelen bij het plegen van uiteenlopende delicten. ${ }^{7,8,9}$

Het verband tussen schulden en criminaliteit is echter wederkerig, waarbij enerzijds het hebben van schulden geassocieerd wordt met een grotere kans op het plegen van delicten en anderzijds het hebben van een strafblad geassocieerd wordt met het hebben van hogere schulden. ${ }^{10,11} \mathrm{Zo}$ kunnen financiële problemen bijdragen aan een grotere kans op het plegen van criminaliteit, bijvoorbeeld

* Dr. Rosa Koenraadt is universitair docent Criminologie aan de Universiteit Leiden. Dr. Anja Dirkzwager is senior onderzoeker bij het Nederlands Studiecentrum Criminaliteit en Rechtshandhaving. Prof. dr. Paul Nieuwbeerta is hoogleraar Criminologie aan de Universiteit Leiden.

1 F. Westhof, L. de Ruig \& A. Kerckhaert, Huishoudens in de rode cijfers. Over schulden van Nederlandse huishoudens en preventiemogelijkheden, Zoetermeer: Panteia 2015.

2 M.G.C.J. Beerthuizen e.a., Vierde meting van de monitor nazorg ex-gedetineerden, Den Haag, WODC, 2015.

3 G. Weijters, J.J. Rokven \& S. Verweij, Monitor nazorg (ex-)gedetineerden - meting 5, Den Haag: WODC 2018.

4 E. Münster e.a., 'Over-indebtedness as a marker of socioeconomic status and its association with obesity: a cross-sectional study', BMC Public Health 2009, 9, p. 286.

5 A.K. Shah, S. Mullainathan \& E. Shafir, 'Some consequences of having too little', Science 2012, 338, p. 682-685.

6 A. Mani e.a., 'Poverty impedes cognitive function', Science 2013, 341, p. 976-980.

7 M. Hoeve e.a., 'A systematic review of financial debt in adolescents and young adults: Prevalence, correlates and associations with crime', PloS one 2014, 8, e104909.

8 M. Aaltonen, A. Oksanen \& J. Kivivuori, 'Debt problems and crime', Criminology 2016, 2, p. 307-331.

9 M. Hoeve e.a., 'Financial problems and delinquency in adolescents and young adults: A 6-year three-wave study', Crime \& Delinquency 2016, 11, p. 1488-509.

10 Aaltonen, Oksanen \& Kivivuori 2016.

11 Hoeve e.a. 2016. 
wanneer geld nodig is om in levensonderhoud te voorzien. ${ }^{12}$ Ook blijken vermogensdelicten en drugshandel vaker voor te komen bij mensen met financiële stress, wat kan duiden op pogingen om financiële problemen te verhelpen door middel van criminaliteit. ${ }^{13}$ Anderzijds kan het betalen van een geldboete of schadevergoeding na een veroordeling juist leiden tot het ontstaan of verergeren van financiële problematiek. ${ }^{14}$

Ook in Nederland blijken mensen met schulden, ongeacht leeftijd of geslacht, een aanzienlijk hogere kans te hebben op het plegen van uiteenlopende delicten dan mensen zonder schulden. ${ }^{15}$ Zo blijken schulden onder adolescenten en jongvolwassenen een risicofactor voor crimineel gedrag, en blijkt andersom dat criminaliteit een risicofactor is voor het hebben van schulden. ${ }^{16}$ Tevens is aangetoond dat ex-gedetineerden met een verslaving in Nederland grote moeite hebben uit de schulden te geraken, wat een belemmerende werking lijkt te hebben op de reintegratie. ${ }^{17}$ De afgelopen jaren wordt daarom getracht meer samen te werken tussen instanties zoals de reclassering en schuldhulpverlening, zodat de financiële problematiek een vast onderdeel wordt van het re-integratietraject. ${ }^{18}$

Theoretisch is het tevens aannemelijk dat de stress en gedragingen die gepaard gaan met schulden een wederzijds verband vertonen met het plegen van criminaliteit. Enerzijds wordt zowel het plegen van criminaliteit als het hebben van financiële problemen in de literatuur in verband gebracht met zelfcontrole. ${ }^{19}$ Volgens de zelfcontroletheorie van Gottfredson en Hirschi ${ }^{20}$ kan een laag niveau van zelfcontrole tot meer impulsief gedrag en mogelijk criminaliteit leiden. Maar ook Sampson en Laubs concept van cumulative disadvantage ${ }^{21}$ is hier van toepassing. Aangezien financiële problemen zowel als een oorzaak als een consequentie van crimineel gedrag kunnen fungeren, kunnen deze problemen telkens verergeren. Op die manier kan een neerwaartse spiraal ontstaan van schulden en criminaliteit en is het wenselijk deze spiraal te doorbreken.

Hoewel verschillende nationale en internationale studies aantonen dat er een duidelijk verband bestaat tussen het hebben van schulden en criminaliteit, is er tot op heden nog weinig bekend over het daadwerkelijke effect en de manier

12 N.E. Turner e.a., 'The relationship of problem gambling to criminal behavior in a sample of Canadian male federal offenders', Journal of Gambling Studies 2009, 2, p. 153-169.

13 R.B. Felson e.a., 'Having a bad month: General versus specific effects of stress on crime', Journal of Quantitative Criminology, 28, p. 347-363.

14 A. Harris, H. Evans \& K. Beckett, 'Drawing blood from stones: Legal debt and social inequality in the contemporary United States', American Journal of Sociology 2010, 6, p. 1753-1799.

15 M. Blom, G. Weijters \& A.M. Van der Laan, Problemen met geld en delinquent gedrag van adolescenten, Den Haag: WODC 2011.

16 Hoeve e.a. 2014.

17 N. Jungmann e.a., Gevangen in schuld, Utrecht: Hogeschool Utrecht 2014.

18 J. Hanrath e.a., 'Jij bent toch van de schulden?': project verbeterde samenwerking tussen schuldhulpverlening en reclassering in Amsterdam, Amsterdam: Hogeschool van Amsterdam 2018.

19 J. Gathergood, 'Self-control, financial literacy and consumer over-indebtedness', Journal of Economic Psychology 2012, 33, p. 590-602.

20 M.R. Gottfredson \& T. Hirschi, A General Theory of Crime, Californië: Stanford University Press 1990.

21 R.J. Sampson \& J.H. Laub, 'A life-course theory of cumulative disadvantage and the stability of delinquency', Developmental theories of crime and delinquency 1997, 7, p. 133-161. 
waarop schulden een rol kunnen spelen bij het plegen van criminaliteit. Op basis van geregistreerde data blijkt wel dat perioden met schulden direct gelinkt worden aan verhoogde criminaliteitscijfers, ongeacht inkomen en andere metingen van sociaaleconomische status. ${ }^{22}$ Ook lijkt er onder adolescenten en jongvolwassenen een wederzijds effect te vinden van schulden en criminaliteit, waarbij het effect van financiële problemen op het plegen van criminaliteit het meest sterk is. ${ }^{23}$ De bestaande onderzoeken naar de directe invloed van schulden op crimineel gedrag worden tot op heden echter belemmerd door een gebrek aan informatie over: (1) verschillende typen schulden en de hoogte daarvan, (2) informele schulden, en (3) de situatie op andere levensdomeinen.

Het vorenstaande maakt duidelijk dat er zowel theoretisch als empirisch, in binnen- en buitenland, aanwijzingen zijn voor de relatie tussen schulden en criminaliteit. Tot op heden is echter niet duidelijk op welke manier verschillende soorten schulden een rol kunnen spelen bij het plegen van uiteenlopende vormen van criminaliteit. Er bestaat zodoende nog altijd weinig criminologische kennis over de link tussen schulden en criminaliteit. Aangezien schulden ernstige gevolgen kunnen hebben en het merendeel van de gedetineerden in Nederland schulden heeft, is het echter van belang te achterhalen op welke manier schulden een rol kunnen spelen bij het plegen van criminaliteit, opdat deze informatie ingezet kan worden om de schuldenproblematiek van veroordeelden en/of gedetineerden te stabiliseren en te verbeteren.

In dit artikel willen wij een eerste aanzet doen voor nader onderzoek naar de rol van verschillende typen schulden bij het plegen van criminaliteit. Omdat het merendeel van de gedetineerden schulden heeft en het effect van detentie op schulden na vrijlating goed te bestuderen is, zullen wij in dit artikel in eerste instantie inzoomen op de Nederlandse gevangenispopulatie. We willen hierbij nagaan wat voor typen schulden gedetineerden hebben en in hoeverre de verschillende schulden veranderen na detentie. De onderzoeksvragen die in dit artikel centraal staan zijn:

1 Wat voor typen schulden hebben gedetineerden in Nederland?

2 In hoeverre hangt het hebben van verschillende typen schulden samen?

3 In hoeverre hangt het hebben schulden tijdens en na detentie samen?

4 Wat zijn de achtergrondkenmerken van gedetineerden die samenhangen met het hebben van schulden?

Hiermee zullen wij de eerste bevindingen van een grotere studie naar de link tussen schulden en criminaliteit tonen. Op deze manier hopen wij inzichten over de rol van schulden bij criminaliteit te vergroten en de discussie over de rol van schulden binnen het strafrecht verder te stimuleren. 


\section{Methoden}

\section{Participanten}

In deze bijdrage wordt gebruikgemaakt van de resultaten van het Prison Project, een grootschalig onderzoek naar (de gevolgen van) detentie en uiteenlopende levensdomeinen van (ex-)gedetineerden in Nederland. Binnen het Prison Project zijn data verzameld door middel van gestructureerde interviews die zijn afgenomen onder gedetineerden op verschillende momenten tijdens en na afloop van de detentieperiode. Voor het onderzoek kwamen mannelijke gedetineerden in aanmerking die in de periode tussen oktober 2010 en maart 2011 in voorlopige hechtenis zijn genomen. Andere selectiecriteria waren dat gedetineerden de leeftijd tussen 18 en 65 jaar hadden en in Nederland geboren waren. ${ }^{24}$ Op basis hiervan voldeden 3981 personen aan de selectiecriteria, van wie 2837 personen zijn benaderd. Dit gebeurde ongeveer drie weken nadat gedetineerden in voorlopige hechtenis waren genomen Uiteindelijk hebben in totaal 1904 gedetineerden deelgenomen aan de eerste meting tijdens detentie (D1-meting), 946 gedetineerden hebben zes maanden na vrijlating deelgenomen (R1-meting) en 964 gedetineerden namen 24 maanden na vrijlating deel (R2-meting). De interviews duurden gemiddeld anderhalf uur en werden afgenomen door getrainde interviewers in een besloten kamer. Deelname aan het onderzoek was op vrijwillige basis, de respondenten ontvingen geen beloning.

\section{Instrumentarium en analyses}

De interviews met gedetineerden zijn afgenomen aan de hand van gestructureerde vragenlijsten over verschillende levensdomeinen, zoals op het gebied van werk, opleiding, relaties, drugs- en alcoholgebruik, inkomen en schulden. Om de typen en hoogte van de schulden te meten is bij zowel de D1- als de R1- en R2meting allereerst gevraagd of er sprake was van schulden en/of leningen. Bij een bevestigend antwoord is gevraagd naar de aanwezigheid en hoogte van de schuld bij twaalf verschillende schuldeisers en een overige categorie schuldeisers. Hierbij zijn ook informele schulden bij vrienden of familie opgenomen; de schuld van een hypotheek is niet meegenomen. Daarnaast is een aantal aanvullende vragen gesteld over het wel of niet financieel rond kunnen komen, ervaring met deurwaarders en het in onderpand geven van spullen.

In dit artikel zijn de schulden tijdens detentie (D1-meting) en zes maanden na detentie (R1-meting) met elkaar vergeleken. Schulden tijdens detentie (D1) betreffen in dit onderzoek de schulden aan het begin van detentie, aangezien de gedetineerden ongeveer drie weken na binnenkomst in de penitentiaire inrichting zijn geïnterviewd. In dit onderzoek is zowel gekeken naar het wel of niet voorkomen van schulden als de hoogte van de schuld. Bij de analyses bleek een klein aantal respondenten onwaarschijnlijk hoge schuldbedragen te hebben opgegeven. Hoewel het mogelijk is dat schulden erg hoog oplopen, is ervoor gekozen om de 
respondenten met een schuld hoger dan 1 miljoen te verwijderen uit de analyses. Dit gaat om drie respondenten in de eerste meting en drie respondenten in de tweede meting.

Verder is gebleken dat niet alle vragen door de respondenten zijn beantwoord. Zo hebben sommige respondenten aangegeven schulden te hebben, maar vervolgens geen enkele schuldeiser genoemd. Bij analyses van het wel of niet voorkomen van schulden per schuldeiser zijn deze personen niet meegenomen, omdat niet vastgesteld kon worden of zij wel of geen schulden hebben. Ook hebben sommige respondenten aangegeven schulden te hebben bij één of meerdere schuldeisers, maar hebben zij geen hoogte van de schulden opgegeven. Bij het berekenen van de gemiddelde hoogte van de schulden, in totaal en per schuldeiser, zijn deze personen niet meegenomen in de analyse, omdat zij aangeven meer dan 0 euro schuld te hebben maar er niet berekend kan worden hoeveel.

In totaal hebben we in de eerste meting tijdens detentie (D1) informatie van 1894 gedetineerden over het wel of niet hebben schulden. Daarvan hebben er 1097 aangegeven dat ze dat hadden en 925 gedetineerden hoe hoog de schuld is. In de tweede meting zes maanden na detentie (R1) hebben we van 935 gedetineerden informatie of zij wel of geen schulden hebben, 560 gaven aan dat ze dat hadden, en 512 personen hebben de hoogte van de schuld opgegeven. Om de schuldensituatie van personen tijdens D1 en R1 te vergelijken hebben we van 883 personen relevante informatie over het wel of niet hebben van schulden van zowel de situatie tijdens als na detentie, en van 767 personen relevante informatie over de hoogte van de schulden in beide situaties.

In deze bijdrage wordt een aantal eerste beschrijvende analyses getoond om de schuldenproblematiek onder een groep gedetineerden in kaart te brengen. Om de samenhang tussen de prevalentie en de hoogte van de schulden tijdens en na detentie te berekenen zijn correlaties en regressieanalyses uitgevoerd. Om de achtergrondkenmerken van gedetineerden met schulden te bepalen zijn verschillende categorieën gemaakt op grond van het samenvoegen van categorieën uit de interviews. Zo zijn respondenten opgedeeld in drie opleidingscategorieën op basis van lager onderwijs (laag), middelbaar onderwijs (middel) en hoger onderwijs (hoog). Legaal inkomen is opgedeeld in drie categorieën op basis van een inkomen tot 800 euro (laag), 800-1400 euro (middel) en hoger dan 1400 euro (hoog). De woonsituatie is onderverdeeld in het hebben van een eigen woning of huurhuis (eigen (huur)huis), het hebben van een kamer of inwonend bij anderen (inwonend) en het wonen in een tehuis, wisselende adressen of zwevend (dakloos). De verschillen tussen de categorieën zijn geanalyseerd met behulp van beschrijvende statistiek en regressieanalyses.

\section{Resultaten}

Typen schulden tijdens en na detentie

Naar aanleiding van de eerste deelvraag is onderzocht hoeveel gedetineerden schulden hebben en welke schulden zij aangeven. In tabel 1 is te zien dat tijdens detentie (D1) 1097 van de 1894 respondenten (57\%) aangeeft schulden te heb- 
ben. Iets meer dan een vijfde van alle gedetineerden geeft aan schulden bij het Centraal Justitieel Incassobureau (CJIB) te hebben (21,9\%), ook een vijfde bij de zorgverzekering (21\%) en rond de 16,6\% geeft aan schulden te hebben bij de bank. Hierna volgen schulden bij telefoonprovider (15\%), familie en vrienden $(6,8 \%)$ en winkels $(4,5 \%)$. De gemiddelde hoogte van de schuld, berekend over de groep die de hoogte van de schulden heeft opgegeven $(N=925)$, ligt tijdens detentie op 18.779 euro. Hierbij worden de hoogste schulden gerapporteerd bij de bank (gemiddeld 24.202 euro), overige categorie (gemiddeld 15.662 euro) en creditcardmaatschappijen (gemiddeld 13.761 euro). Tijdens detentie rapporteren respondenten tussen de 1 en 9 schuldeisers te hebben, met een gemiddelde van 2,1 schuldeisers.

Zes maanden na detentie (R1) gaven 560 van de 935 respondenten (60,0\%) aan schulden te hebben, waarbij de gemiddelde schuld op een iets hoger bedrag van in totaal 23.144 euro neerkwam. Ook na detentie rapporteert meer dan een vijfde van de gedetineerden schulden te hebben bij het CJIB $(23,7 \%)$ en bij de zorgverzekering $(23,1 \%)$. Hierna volgen schulden bij de overige categorie (17,5\%), de bank $(16,4 \%)$, telefoon $(13,1 \%)$ en familie en vrienden $(12,8 \%)$. De hoogste schuld wordt genoteerd bij de bank (gemiddeld 25.373 euro), overig (gemiddeld 23.208 euro) en winkels en postorderbedrijven (gemiddeld 11.629 euro). Zes maanden na detentie worden tussen de 1 en 11 schuldeisers gerapporteerd met een gemiddelde van 2,4 schuldeisers. 


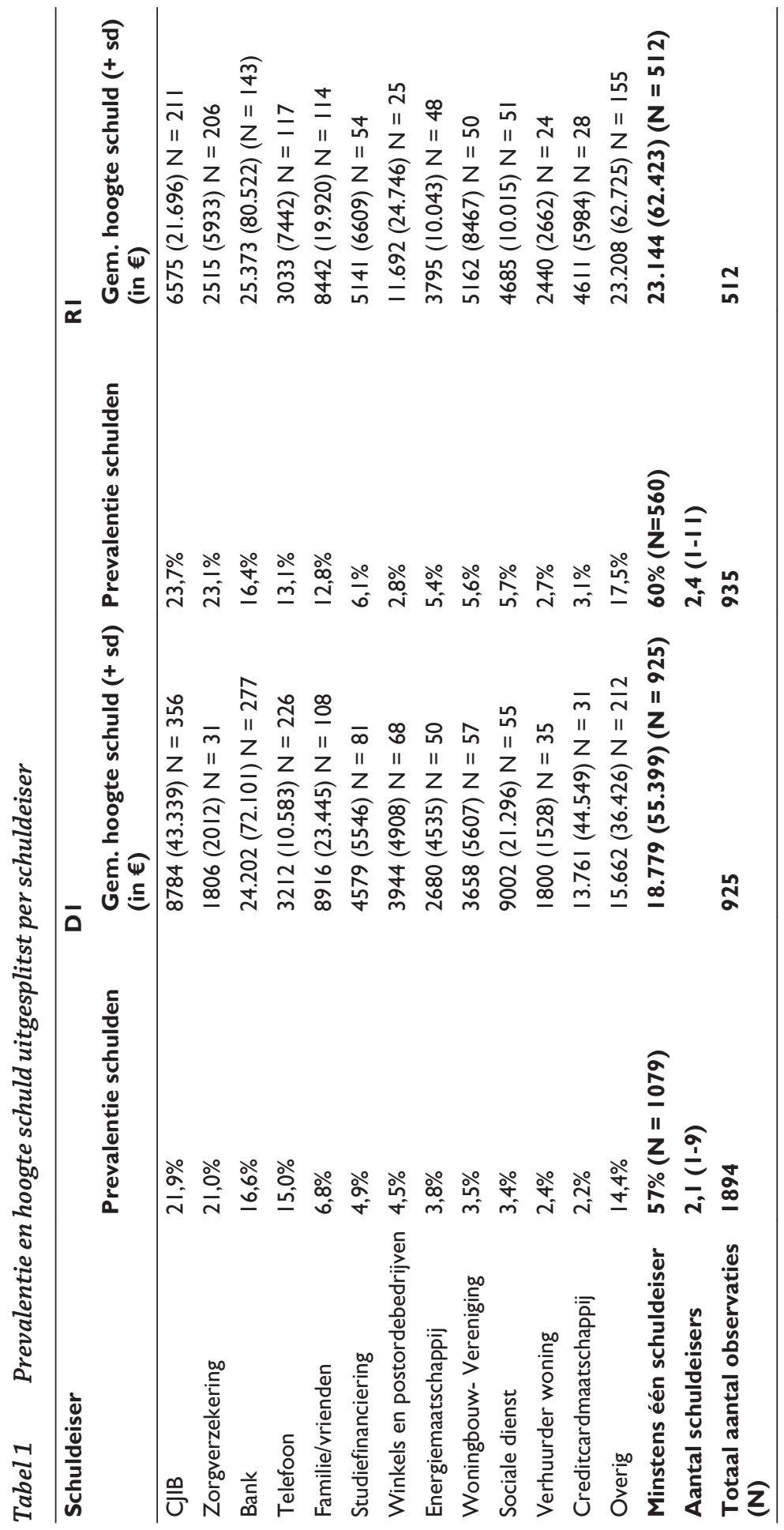




\section{Samenhang verschillende typen schulden}

Om de verschillende typen schulden nader te analyseren is tevens gekeken naar de samenhang tussen alle verschillende schuldeisers tijdens detentie. Het overzicht van de samenhang tussen het wel of niet hebben van verschillende schulden tijdens detentie is te vinden aan de hand van de odds ratio's linksonder in tabel 2. Hieruit blijkt dat het hebben van sommige schulden, zoals bij het CJIB, zorgverzekering en telefoonprovider, samenhangt met specifieke andere schuldeisers. Zo verhogen schulden bij onder andere het $\mathrm{CJIB}(\mathrm{OR}=6,9)$, telefoonprovider $(\mathrm{OR}=$ $9,1)$ of verhuurder $(\mathrm{OR}=18,6)$ aanzienlijk de kans om ook schulden te hebben bij de zorgverzekering. Anderzijds hangt het hebben van schuld bij de creditcardmaatschappij juist niet samen met het hebben van schulden bij de zorgverzekering en is er niet veel samenhang tussen de studieschuld met andere schuldeisers zoals het CJIB, de energiemaatschappij of de sociale dienst.

Voor de samenhang tussen de hoogte van de schulden bij verschillende schuldeisers is gekeken naar de correlaties. Uit tabel 2 blijkt dat de samenhang tussen de opgegeven hoogte van de schuld doorgaans niet hoog is. De hoogste samenhang wordt genoteerd voor de hoogte van de schuld bij de bank en vrienden/familie $(r=, 34)$. Daarna volgt de samenhang tussen de hoogte van de schuld bij de verhuurder van de woning en vrienden/familie $(r=, 23)$ en de hoogte van de schuld bij de zorgverzekering en telefoonprovider $(r=, 20)$.

Ook de samenhang tussen de verschillende schuldeisers na detentie is geanalyseerd, maar omdat hier geen belangrijke verschillen met de schulden tijdens detentie te zien waren, is ervoor gekozen deze tabel hier niet weer te geven. 


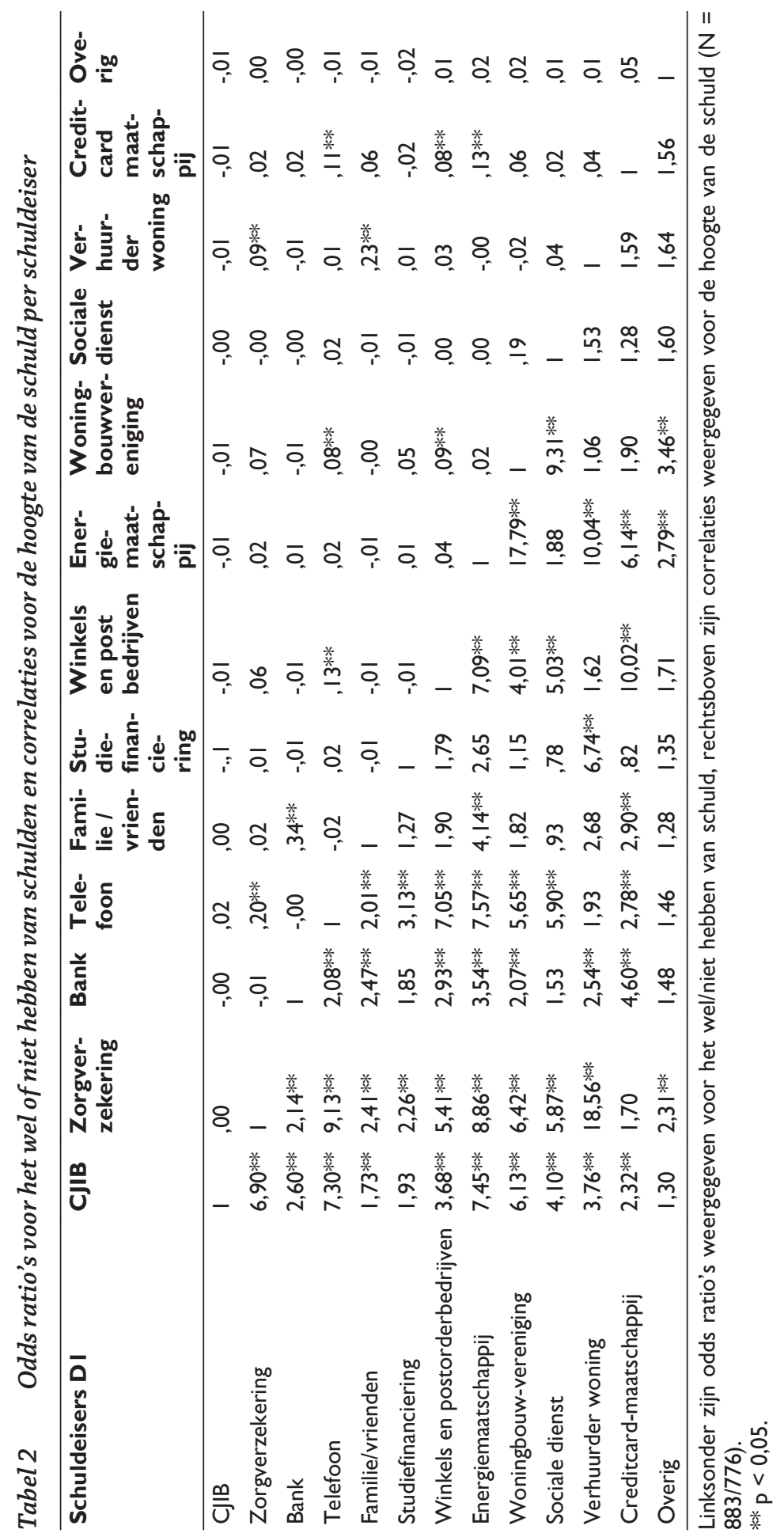




\section{Samenhang van schulden tijdens en na detentie}

De derde deelvraag van het onderzoek betrof de samenhang van de schulden tijdens en na detentie. Uit tabel 3 valt op te maken dat het hebben van schulden tijdens detentie de kans op het hebben van schulden na detentie vergroot. Mensen die enige schulden hebben tijdens detentie, hebben zodoende een grotere kans om schulden te hebben zes maanden na detentie $(O R=9,55)$. Dit resultaat vinden we ook voor schulden bij alle schuldeisers afzonderlijk, behalve voor schulden bij de verhuurder van de woning. Voor alle andere schuldeisers geldt dat wanneer tijdens detentie bij deze schuldeiser schulden worden gerapporteerd, de kans groter wordt om na detentie schulden te rapporteren bij de afzonderlijke schuldeisers.

Ook de samenhang wat betreft de hoogte van de schulden tijdens en na detentie is geanalyseerd. Hieruit blijkt dat gemiddeld voor elke euro schuld tijdens detentie de hoogte van de schuld na detentie met 48 eurocent verhoogd wordt (B $=, 48)$. In tabel 3 is verder te zien dat ook voor de afzonderlijke schuldeisers geldt dat er significant positieve verbanden zijn tussen de D1- en R1-meting, behalve voor de schulden bij de sociale dienst en de verhuurder van de woning.

\section{Tabel 3 Samenhang tussen schulden tijdens D1 en R1}

\begin{tabular}{|c|c|c|}
\hline Schuldeiser & Samenhang schuld DI en RI & $\begin{array}{l}\text { Samenhang hoogte } \\
\text { schuld tijdens DI en RI }\end{array}$ \\
\hline & OR Wel/geen schuld DI en RI & $\begin{array}{l}\text { B (sd) Hoogte schuld DI } \\
\text { en RI }\end{array}$ \\
\hline CJIB & $5,39 * *(0,96)$ &, $05 * *(, 01)$ \\
\hline Zorgverzekering & $6,56 * *(1,19)$ &, $29 * *(, 10)$ \\
\hline Bank & $10,89 * *(2,25)$ & $\mathrm{I}, 00 * *(, 03)$ \\
\hline Telefoon & $8,09 * *(1,76)$ &, $56 * *(, 03)$ \\
\hline Familie/vrienden & $6,5 I^{* *}(I, 74)$ &, $07^{* *}(, 05)$ \\
\hline Studiefinanciering & $33,43 * *(12,17)$ &, $61 * *(, 04)$ \\
\hline Winkels en postordebedrijven & $22,75 * *(9,84)$ &, $49 * *(, 08)$ \\
\hline Energiemaatschappij & $17,34 * *(6,60)$ &, $34 * *(, 09)$ \\
\hline Woningbouwvereniging & $10,37 * *(4,03)$ &, $26 * *(, 12)$ \\
\hline Sociale dienst & $12,00 * *(5,16)$ &, $01(, 02)$ \\
\hline Verhuurder woning & $3,8 \mathrm{I}(2,95)$ &,$- 01(, 09)$ \\
\hline Creditcardmaatschappij & $29,13 * *(13,64)$ &, $33 * *(, 03)$ \\
\hline Overig & $2,29 * *(0,49)$ &, $90 * *(, 06)$ \\
\hline Minstens een schuldeiser & $9,55 * *(1,52)$ &, $48 * *(, 03)$ \\
\hline $\begin{array}{l}\text { Totaal aantal observaties } \\
\text { (N) }\end{array}$ & 883 & 767 \\
\hline
\end{tabular}

** $p<0,05$

\section{Achtergrondkenmerken schulden tijdens en na detentie}

De vierde deelvraag in deze bijdrage betreft het achterhalen van in hoeverre achtergrondkenmerken van gedetineerden samenhangen met het hebben van schul- 
den. De resultaten hiervan zijn weergegeven in tabel 4. Op basis van de regressieanalyses is gekeken of er een verschil bestaat in de mate waarin (wel of geen) schulden worden gerapporteerd tussen verschillende categorieën op basis van onder andere leeftijd, opleiding en woonsituatie. We zullen hier uitsluitend ingaan op de significante verschillen tussen categorieën. Uit de analyses onder 1894 respondenten bij het begin van de detentie (D1) blijkt allereerst dat de gedetineerden ouder dan 30 jaar vaker een schuld rapporteren dan gedetineerden jonger dan 30 jaar. Zo geeft in totaal 52,2\% aan schulden te hebben, terwijl van de gedetineerden ouder dan 30 jaar in totaal $64,0 \%$ schuld rapporteert $(B=, 09)$. Ten tweede blijken gedetineerden met een lage opleiding het vaakst schulden te rapporteren $(63,7 \%)$ ten opzichte van $47,7 \%$ van de gedetineerden met een middelhoge opleiding $(B=-, 12)$ en $53,8 \%$ van gedetineerden met een hoge opleiding $(B=$ $-, 06)$.

Verder blijkt bijna $80 \%$ van de personen die aangeven dakloos te zijn schulden te rapporteren $(B=, 17)$, in vergelijking met $55,8 \%$ van de personen met een eigen huur- of koopwoning en $54,2 \%$ van de respondenten die inwonend zijn bij anderen. In totaal rapporteert $61,4 \%$ van de respondenten zonder werk schulden, ten opzichte van 50\% schulden bij respondenten met werk. Personen die voorafgaand aan detentie werk hadden, hebben iets vaker schulden dan personen zonder werk $(B=-, 07)$. Tot slot blijken personen die eenvoudige diefstal hebben gepleegd het meest vaak schulden te rapporteren $(69,5 \%, \mathrm{~B}=, 09)$, in vergelijking met 52,5\% schulden bij personen die betrokken zijn bij drugsdelicten en 52,1\% schulden bij personen die veroordeeld zijn voor levensmisdrijven. Wat betreft de gemiddelde schuld worden weinig verschillen gevonden. Alleen het ouder zijn dan 30 jaar lijkt een positief verband te vertonen met het hebben van hogere schulden. Zo rapporteren personen boven de 30 jaar een gemiddelde schuld van 32.794 euro en personen onder de 30 jaar een gemiddelde schuld van 7622 euro.

In de R1-meting na detentie worden ongeveer dezelfde bevindingen gevonden. Ook hier blijken gedetineerden met een lage opleiding het vaakst schulden te rapporteren $(65,9 \%)$, ten opzichte van $54,2 \%$ van de gedetineerden met een middelhoge opleiding $(B=-, 10)$ en $55,7 \%$ van gedetineerden met een hoge opleiding $(B=$ -,07). De gedetineerden die na detentie dakloos zijn, geven in $87,9 \%$ van de gevallen aan schulden te hebben $(B=, 17)$, in vergelijking met $56,2 \%$ van de personen met een eigen huur- of koopwoning en $61,4 \%$ van de respondenten die inwonend zijn bij anderen. Tot slot blijken ook na detentie de personen die eenvoudige diefstal hebben gepleegd het vaakst schulden te rapporteren $(74,0 \%, \mathrm{~B}$ $=, 12$ ). Wat betreft de hoogte van de schuld wordt ook in $\mathrm{R} 1$ alleen een duidelijk verschil gevonden tussen leeftijdscategorieën. Zo hebben gedetineerden jonger dan 30 jaar een gemiddelde schuld van 12.672 euro, en gedetineerden ouder dan 30 jaar een gemiddelde schuld van 34.389 euro. 


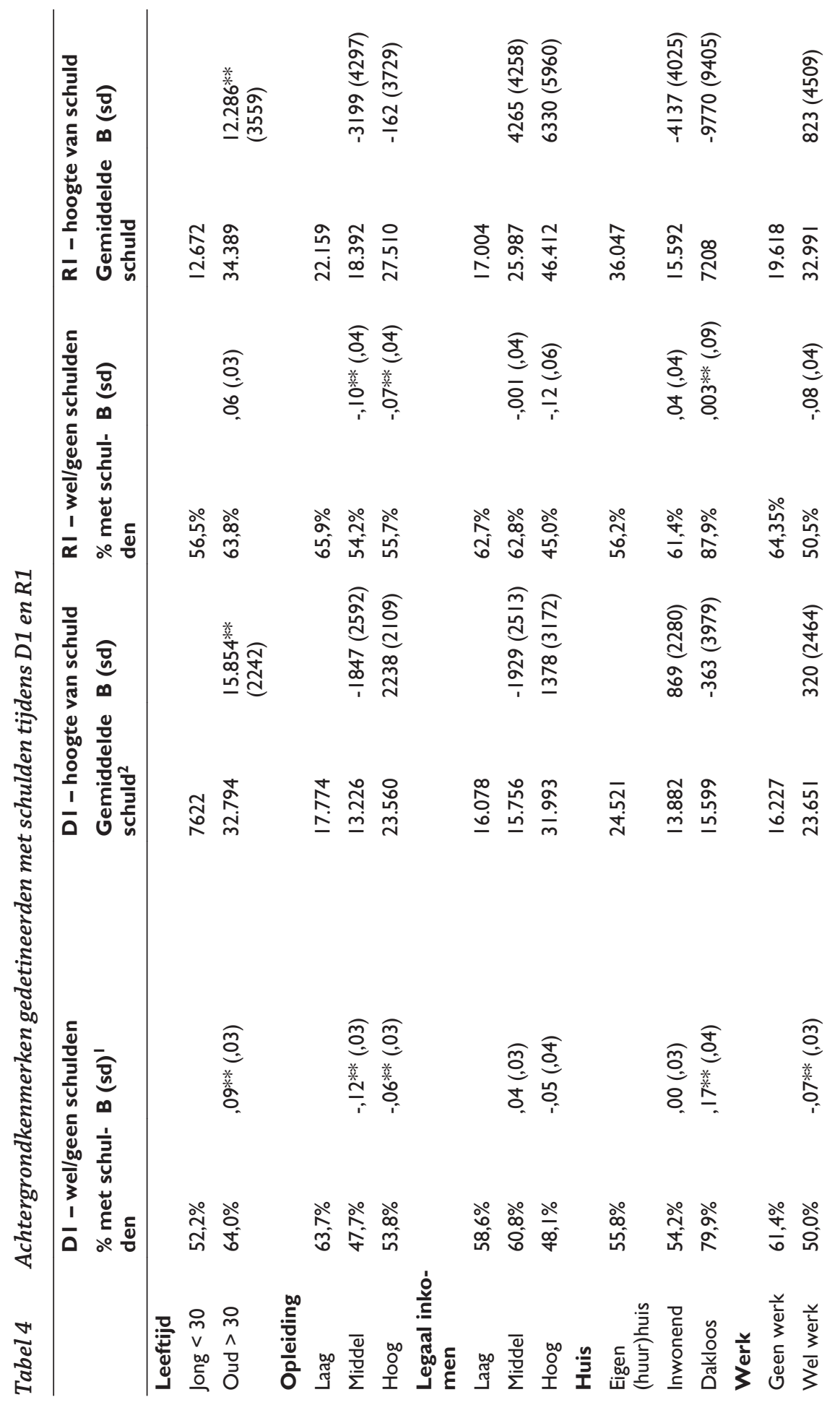




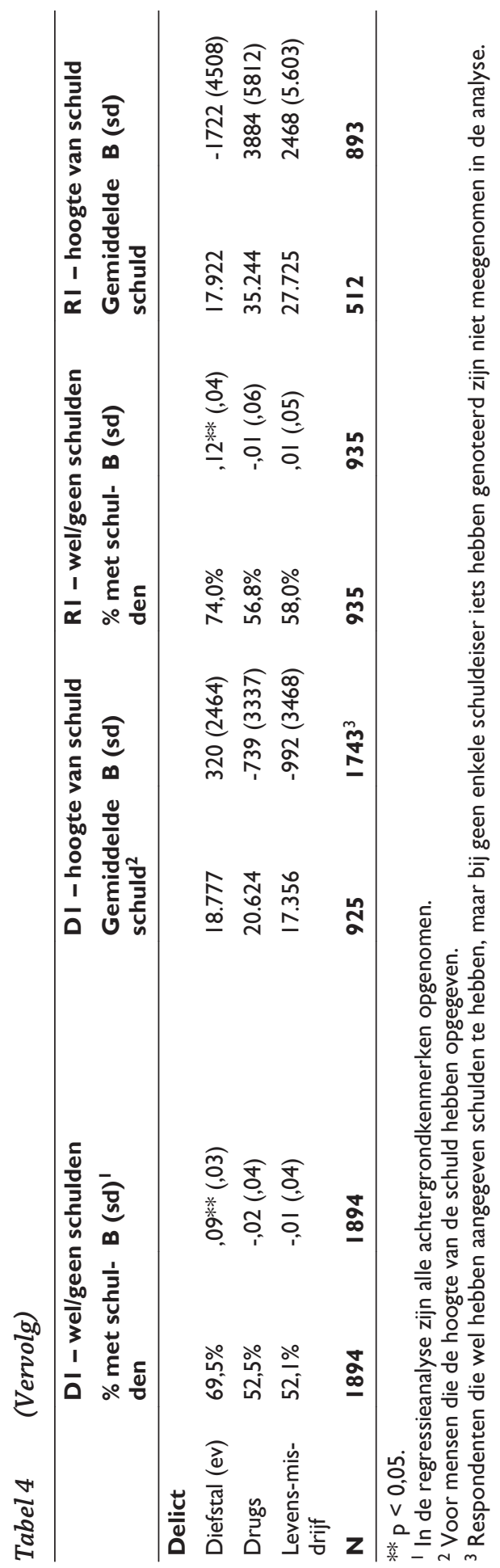




\section{Slotbeschouwing}

In deze bijdrage is ingegaan op de relatie tussen het hebben van schulden en detentie. Hoewel verschillende studies laten zien dat mensen met schulden een verhoogd risico hebben op het plegen van criminaliteit, bestaat er nog weinig inzicht in de verschillende typen en hoogten van de schulden van gedetineerden, en het verloop van de schulden tijdens en na detentie. Om (de gevolgen van) verdere schulden te kunnen stabiliseren en voorkomen is kennis hierover noodzakelijk. In deze studie is daarom een eerste aanzet gedaan om inzichtelijk te maken met wat voor schulden gedetineerden in Nederland te maken hebben en welke achtergrondkenmerken daarmee samenhangen.

Uit de resultaten van het Prison Project blijkt dat, overeenkomstig met eerdere bevindingen, meer dan de helft van de gedetineerden schulden heeft. Na detentie lijkt dit percentage zelfs iets toe te nemen, waarbij personen met schulden ook een hogere schuld rapporteren. Veruit de meeste schulden tijdens en na detentie worden gerapporteerd bij het CJIB en de zorgverzekering. De hoogste schulden worden daarentegen bij de bank en de overige categorie genoteerd. Daarnaast lijkt er een onderscheid gemaakt te kunnen worden tussen verschillende typen schuldeisers, waarbij sommige schulden tijdens detentie, zoals bij het CJIB, de zorgverzekering of de energiemaatschappij, duidelijk samenhangen. Schulden bij de creditcardmaatschappij en een studieschuld vertonen minder samenhang met de meeste andere schuldeisers, zoals met de zorgverzekering of woningbouwvereniging. Op basis van deze resultaten lijkt het aannemelijk dat er verschillende categorieën van schulden onderscheiden kunnen worden. In vervolgonderzoek is het daarom van belang na te gaan welke schulden de grootste problemen opleveren. Zo hoeven niet alle typen en hoogten van schulden tot financiële problemen te leiden en is het aan te raden problematische schulden nader te analyseren.

Verder laat dit onderzoek zien dat het hebben van schulden tijdens detentie de kans vergroot op het hebben van schulden na detentie. Dit geldt zowel voor schulden in het algemeen als voor schulden bij de afzonderlijke schuldeisers. Wat betreft de achtergrondkenmerken die samenhangen met het hebben van schulden, worden de meeste schulden gerapporteerd door gedetineerden ouder dan 30 jaar met een lage opleiding, die dakloos zijn en geen werk hebben. Ook hier dient in het vervolg nader onderscheid gemaakt te worden tussen achtergrondkenmerken en verschillende typen schulden, om zo na te gaan welke groepen de meeste problematische schulden vertonen en hoe bij deze groepen de financiële situatie verbeterd kan worden.

Bij de interpretatie van de resultaten is het verder van belang een aantal kanttekeningen te benoemen. Zo zijn de data verzameld op basis van interviews met gedetineerden, maar is het niet mogelijk na te gaan in hoeverre de schulden overeenkomen met de daadwerkelijke schuld. Zo zijn er respondenten in beide metingen die hebben aangegeven schulden te hebben, maar vervolgens niet hebben vermeld hoe hoog deze schuld is. Omdat personen met ernstige schuldenproblematiek vaak juist geen goed overzicht hebben van de financiële situatie, is het mogelijk dat sommige schulden, mogelijk zelfs de meest problematische, nog onderbelicht blijven. Tevens dient vermeld te worden dat de data van het Prison Project 
vanaf 2010 zijn verzameld en dit inmiddels een vertekening van de resultaten kan opleveren ten opzichte van de huidige situatie. Zo wordt bij het CJIB steeds vaker een betalingsregeling getroffen om aan openstaande boetes te voldoen ${ }^{25}$ en is het aannemelijk dat de hoogten en typen van de schulden fluctuerend zijn over de tijd. Nog steeds blijken echter veel gedetineerden met schulden te maken te hebben. Ondanks het feit dat deze data mogelijk iets verouderd zijn, biedt dit onderzoek de mogelijkheid tot een systematische analyse van verschillende typen schulden van (ex-)gedetineerden.

Met deze bijdrage hebben wij geprobeerd een eerste aanzet te doen binnen een groter onderzoek naar de rol van schulden bij criminaliteit en binnen het strafrecht. De resultaten van het huidige onderzoek bevestigen dat een groot aandeel van de gedetineerden schulden heeft, en is voor het eerst inzichtelijk gemaakt welke typen schulden personen tijdens en na detentie hebben. Waar de afgelopen jaren steeds meer onderzoek wordt verricht naar de negatieve gevolgen van het hebben van schulden, is het van belang dat hier ook binnen de criminologie en het strafrecht meer aandacht voor komt. In vervolgonderzoek zullen wij dan ook op basis van representatieve data en kwalitatieve gegevens verder nagaan in hoeverre verschillende typen schulden daadwerkelijk een rol spelen bij het plegen van criminaliteit en op welke manier schulden mogelijk kunnen verergeren na een veroordeling. Hiermee hopen wij de discussie over (de aanpak van) schulden binnen het strafrecht verder te stimuleren. 